\title{
Co-occurrence and potential resource partitioning between oligochaetes and chironomid larvae in a sediment depth gradient
}

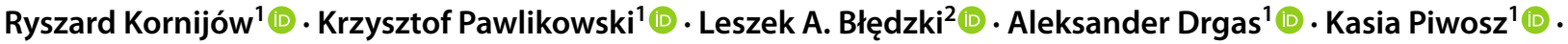

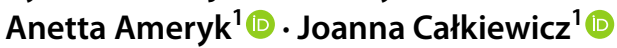

Received: 7 July 2020 / Accepted: 23 March 2021 / Published online: 6 May 2021

(C) The Author(s) 2021

\begin{abstract}
Although detritivorous Tubificinae and chironomid larvae are important groups in functioning of both, fresh and brackish water ecosystem, their co-occurrence patterns in sediment is weakly known. We carried out two-year-long research in the brackish Vistula Lagoon (southern Baltic Sea), where both Tubificinae (Limnodrilus hoffmeisteri and Potamothrix hammoniensis) and larvae of Chironomus balatonicus occur in high densities. Because of different source of their food, we hypothesized that the ecological interactions between those two groups of detritivores are not antagonistic, thus allowing for their co-occurrence along the depth of sediment profile with lack of competition for space. Here we show that maximum burrowing depth, occasionally reaching $25 \mathrm{~cm}$ was significantly affected by the total density of the each group in the entire core. Tubificinae and C. balatonicus showed the highest density at 0-10 $\mathrm{cm}$ depth, where they co-occurred most frequently, with significant co-occurrence in the layers of $0-2 \mathrm{~cm}$ and $2-5 \mathrm{~cm}$. We propose a hypothetical model of interactions between apparently the same functional groups and the complementary role they play in sediment reworking. It points to their coexistence in the shared microhabitat, but using space and food resources differently. Also, the consequences of their activity and habitat structuring are opposite-Chironomus larvae mostly affect the deeper layers of the sediments, while Oligochaeta both the deeper and surface layers. Thus, their requirements and ecological roles seem not to overlap, preventing competitive exclusion and allowing for co-occurrence.
\end{abstract}

Keywords Bioturbation · Detritus-feeders $\cdot$ Macroinvertebrates $\cdot$ Vertical distribution $\cdot$ Zoobenthos $\cdot$ Baltic lagoon

\section{Introduction}

Invertebrate benthic communities inhabiting freshwater and brackish water ecosystems are composed of different taxonomic groups. Most of them live on or just below the surface of the bottom sediments, but some burrow sediments to a depth of several dozen $\mathrm{cm}$. The latter particularly include Tubificinae and larvae of several species of Chironomidae, mainly from genus Chironomus. They are among the most globally widespread benthic invertebrates (Pinder 1995;

Ryszard Kornijów

rkornijow@mir.gdynia.pl

1 National Marine Fisheries Research Institute, Gdynia, Poland

2 Department of Environmental Studies, Mount Holyoke College, South Hadley, MA, USA
Timm and Martin 2015). Because they belong to so-called infauna (deep burrowers), it can be assumed that the ecological interactions can take place not necessarily in the entire inhabited sediment depth but in its specific layers (Whitlatch 1980). However, vertical distribution of these groups in sediments has been rarely studied simultaneously, and suffers the lack of quantitative analysis of the relationships between these groups (Kajak and Dusoge 1971; Milbrink 1973; Newrkla and Wijegoonawardana 1987; Kornijów and Moss 1997). The potential impact of biotic factors driving their distribution has been therefore largely ignored, except for the effect of fish (Van de Bund and Groenendijk 1994; Kornijów 1997; Persson and Svensson 2006) and mainly abiotic factors including pollution (Mucha et al. 2004; Como and Magni 2009), and content of organic matter in sediments (Newrkla and Wijegoonawardana 1987; Mathooko 1995; Magni et al. 2008; Beghelli et al. 2012). In fact, the traditionally perceived role of oligochaetes and chironomid larvae 
primarily involves processing of organic matter as both groups are classified as detritivores (Covich et al. 1999).

Belonging to the same trophic guild can be expected to lead to competition for food resources (Odum 1971). This also was suggested for benthic detritivores such as oligochaetes and chironomids (Brinkhurst and Kennedy 1965; Jónasson 1972; Moss and Timms 1989; Como and Magni 2009; Ojaveer 2017). Vos (2001) hypothesized the ability to avoid competitive interactions between Tubificinae and Chironomus larvae due to the possibility of collecting food particles of different sizes, determined by the width of the mouth. Food particles ingested by $4^{\text {th }}$ larvae stage of e.g., Chironomus balatonicus Devai, Wuelker \& Scholl indeed reach up to $500 \mu \mathrm{m}$ (Kornijów et al. 2019), i.e. approximately at least twice the value found e.g. in Limnodrilus (Juget et al. 1979; Fukuhara 1987). Different source of food can also be considered as an argument precluding the possibility of competing for food. Tubificinae ingest food particles from deeper sediment layers (Davis 1974; Nogaro et al. 2007; Mermillod-Blondin 2011; Timm and Martin 2015), while Chironomus larvae feed primarily by filtering the overlying water or by collecting particles from the sediment surface around their burrows (Walshe 1947; McLachlan and Cantrell 1976; McCall and Tevesz 1982; Proulx and Hare 2014).

Given the above, we hypothesize that the interspecific interactions between detritivorous Tubificinae and Chironomus larvae at both the individual and community level are not antagonistic, sensu Holland and DeAngelis (2009), allowing for their co-occurrence along the depth of sediment profile with lack of competition for space. In order to test this hypothesis, we conducted two-year-long research in soft bottom sediments of the eutrophicated Vistula Lagoon, where both Tubificinae and C. balatonicus larvae occur in high densities (Ezhova et al. 2005; Kornijów and Pawlikowski 2015). Specifically, we expected simultaneous presence of representatives of these groups in both, time and space along the sediment core showing the positive relationship between their densities and co-occurrence.

\section{Materials and methods}

\section{Study site}

The Vistula Lagoon located in the south-eastern part of the Baltic Sea, is large $\left(838 \mathrm{~km}^{2}\right)$ but shallow (mean depth $2.5 \mathrm{~m}$; max. depth $5.2 \mathrm{~m}$ ) and strongly elongated water body, oriented north-east to south-west. The western part of the lagoon with an area of $328 \mathrm{~km}^{2}$ is located in the Polish territory, whereas the remaining part is in Russia. The lagoon's basin is separated from the Baltic Sea by the Vistula Spit in the north, and connected with the sea by the Baltiysk Strait.
Salinity decreases from 6.5 PSU at the Baltiysk Strait to $<1$ at the mouth of the large rivers in the western basin. No regular tides occur in the lagoon. The climate is transitional, from moderate maritime to moderate continental.

Concentrations of nutrients in the water column are high $\left(\mathrm{N}_{\text {tot. }}=2.1-2.3 \mathrm{mg} \mathrm{L}^{-1} ; \mathrm{P}_{\text {tot. }}=0.10-0.11 \mathrm{mg} \mathrm{L}^{-1}\right)$, favouring development of cyanobacteria (Nawrocka and Kobos 2011; Kownacka et al. 2020). Water transparency is low (Secchi depth fluctuates around $50 \mathrm{~cm}$ ). This is a result of relatively high chlorophyll- $a$ concentrations (22.9-54.3 $\mu_{\mathrm{g} \mathrm{L}}^{-1}$ ), and also high concentrations of total suspended solids (42.7-54.5 $\mathrm{mg} \mathrm{L}^{-1}$ ), caused by frequent resuspension in the shallow area exposed to wind action (Chubarenko and Margoński 2008; Piwosz et al. 2016; Kornijów 2018). Bottom sediments are primarily composed of sand in the hydrodynamic-active, shallow zone at a depth of up to $1.5-2 \mathrm{~m}$. Deeper regions are dominated by fine-grained clayey silt. The near-bottom water layers are well oxygenated, even during long winters under ice cover (Kornijów et al. 2020).

The samples were collected at two sites, in the eastern $\left(54.39190^{\circ} \mathrm{N}, 19.68360^{\circ} \mathrm{E}\right)$ and in the middle $\left(54.35010^{\circ} \mathrm{N}\right.$, $19.48480^{\circ} \mathrm{E}$ ) part of the open-water area of the Polish part of the lagoon at a depth of approximately $3 \mathrm{~m}$, where soft sediments are composed of clayey silt (Fig. 1). Because the differences in the faunal composition between the sites in this highly homogenous environment were negligible, all the data collected were pooled.

\section{Field survey and laboratory analyses}

The field study was conducted in spring, summer, and autumn in 2010 and 2011. On each occasion, from 5 to 15 replicate standardized sediment cores $6 \mathrm{~cm}$ in diameter and $30 \mathrm{~cm}$ long were taken by means of a gravity sampler (UWITEC Ltd., Austria) equipped with a drive rod. Each core was sectioned into 7 layers with a slicer equipped with a sub-sample holder and centimetre scale (Kornijów 2013). The upper layer of the core was $2 \mathrm{~cm}$ thick, the second $3 \mathrm{~cm}$, and the following five $5 \mathrm{~cm}$ thick. This interval is corresponding with individual length of worms (Matisoff et al. 1999), and at most twice as large as the length of forth instar of Chironomus larvae (Armitage et al. 1995). The volume of core sections ranged from 0.056 to $0.141 \mathrm{~L}$. Each sediment section was washed separately through $0.3 \mathrm{~mm}$ mesh. Invertebrates were sorted out by eye on a white tray filled with water, and preserved in $4 \%$ formaldehyde solution. Altogether 434 sediment sections were collected and processed. The deepest sediment layer $(25-30 \mathrm{~cm})$ was uninhabited by invertebrates, and therefore it was excluded from analysis.

Additional $30 \mathrm{~cm}$ long sediment cores for analyses of organic matter and bacteria were sampled simultaneously with macroinvertebrates on each sampling date in the first and the second year, respectively. They were collected and 
Fig. 1 Research area with sampling stations marked by dots. GIS layers of land cover after OpenStreetMap (2020), bathymetry according to Chubarenko (2008)-modified, and shore line after Maritime Office in Gdynia (2015)—modified

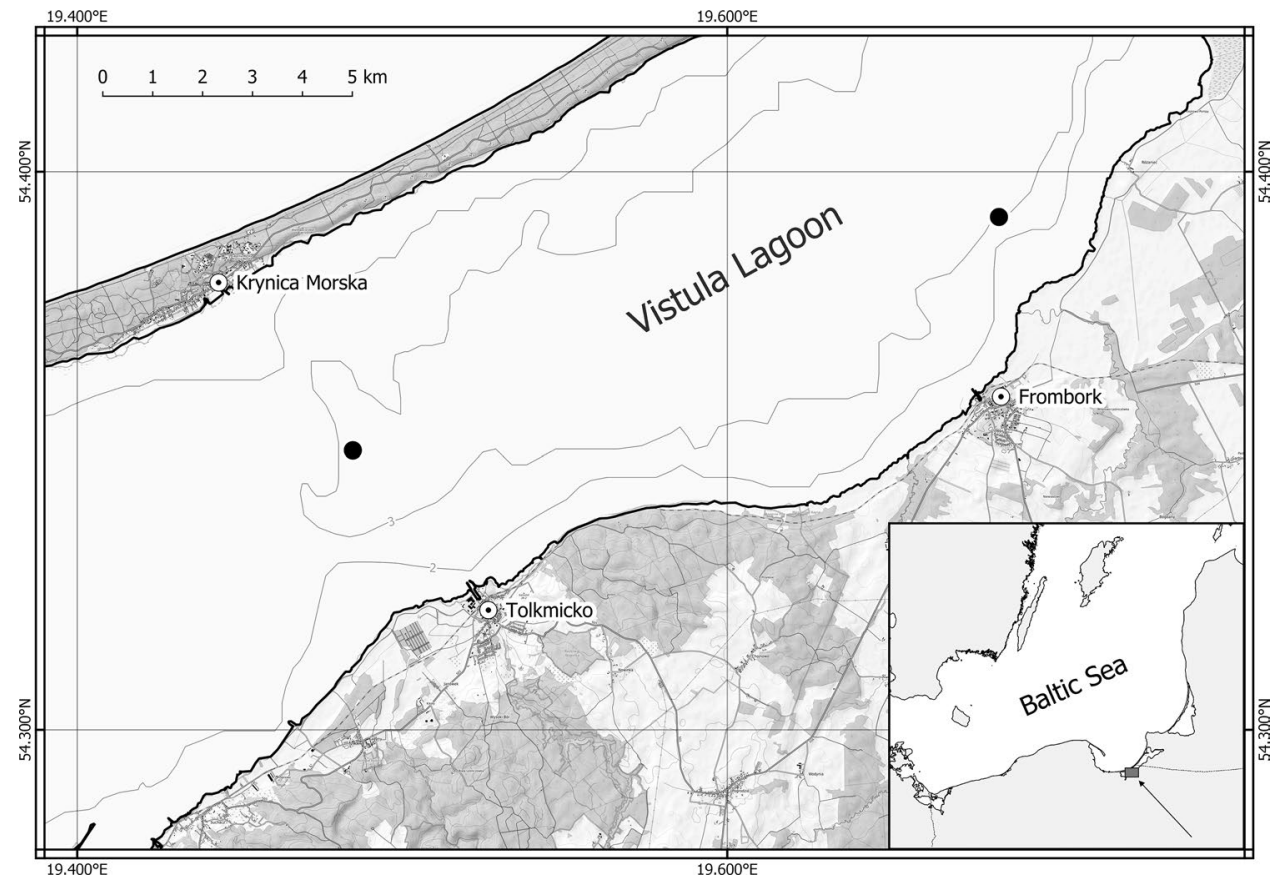

sectioned using the same equipment as in the case of benthic fauna samples. The organic matter and bacteria samples were secured in a cooler with ice immediately after sampling, and later in the laboratory were frozen and stored at $-20{ }^{\circ} \mathrm{C}$ until the analysis. The percentage of organic matter was calculated as a percentage weight loss during the ignition (LOI) of dried sediment burned at $550{ }^{\circ} \mathrm{C}$ for $24 \mathrm{~h}$. Bacteria in sediments were analysed according to Epstein and Rossel (1995). Bacterial cells from 30 fields of view were counted under $1000 \times$ magnification using epifluorescent microscopy Nikon Eclipse 80i.

\section{Data analyses}

Tubificinae and the majority of chironomid larvae were identified according to Timm (1999) and Andersen et al. (2013), respectively. The species affiliation of Chironomus (not distinguished morphologically) was adopted based on karyological studies by Markiyanova (2018), indicating that this genus in the central part of the lagoon is represented solely by one species, namely $C$. balatonicus.

Because the sediment layers differed in thickness (and volume), the density of invertebrates in subsequent layers was expressed per sediment $\mathrm{L}$ to allow comparison of invertebrates abundance (Kornijów and Pawlikowski 2016). The total density in the entire inhabited core was expressed in the most often used unit in benthos research as the number of individuals per $\mathrm{m}^{2}$.

Frequency of occurrence was calculated as a percentage of samples (representing a given section of sediment core) in which one of the groups (Tubificinae or larvae of C. balatonicus) or two groups occurred together.

Pearson's Chi-Square Test for $2 \times 2$ tables was performed to check the significance of co-occurrence of the groups with the guidance and assumption given by Gotelli and Ellison (2013). Associations between densities of the fauna and maximum burrowing depth was identified using linear regression. Shapiro-Wilk test for normal distribution and Levene test for equal population variances were conducted. Because of an unequal variances or non-normal distribution several non-parametric tests were used:

- Kruskal-Wallis test $(\mathrm{H})$ was applied for the determination of the effect of sediment depth on the content of organic matter and densities of bacteria.

- Friedman test $\left(\chi^{2}\right)$ was applied to test the effect of sediment depth on the density of $C$. balatonicus and Tubificinae, and Friedman post-hoc test after Nemenyi was applied for the detailed analyses.

- Wilcoxon signed-rank test (T) was applied to check the significance of differences in the densities of $C$. balatonicus and Tubificinae between two sampling years.

Statistical tests were performed with the application of STATISTICA 10 software (StatSoft 2011). 


\section{Results}

\section{Invertebrate density and distribution}

The qualitative composition of benthic macroinvertebrates was very poor and consisted of only 7 taxa: Potamothrix hammoniensis (M.), Limnodrilus hoffmeisteri C. (Tubificinae), as well as larvae of Chironomus balatonicus, Microchironomus tener (K.), Procladius sp. and Tanytarsini juv. (Diptera; Chironomidae). Single specimens of Potamopyrgus antipodarum (G.) (Gastropoda) were also encountered. Most samples showed high percentage of Tubificinae and $C$. balatonicus. The mean share of $P$. hammoniensis, $L$. hoffmeisteri, and C. balatonicus in the total density of benthic fauna were 42,7 , and $19 \%$, respectively.

Mean total density \pm SD (Standard Deviation) of invertebrates was $7044 \pm 4493$ ind. $\mathrm{m}^{-2}$ and ranged from 2806 to 16,269 ind. $\mathrm{m}^{-2}$. During the second sampling year the densities of $C$. balatonicus were significantly lower [Wilcoxon Test: $\mathrm{T}(n=16)=23 ; p=0.02]$ and those of Tubificinae did not change [Wilcoxon Test: $\mathrm{T}(n=13)=28 ; p=0.21$ ].
Maximum burrowing depth differed between the taxa. Tubificinae and $C$. balatonicus were found to a depth of $25 \mathrm{~cm}$, and the presence of the remaining taxa was limited to the upper $5 \mathrm{~cm}$ surface layer (Fig. 2). The depth below $25 \mathrm{~cm}$ was uninhabited by macroinvertebrates. The density of Tubificinae and $C$. balatonicus in particular core sections changed with sediment depth in most of the examined seasons (Table 1). In most cases, however, the Friedman post-hoc test did not detect significant differences in density between the particular sediment layers. The exception was $P$. hammoniensis, whose densities significantly differed between the two deepest $(15-20$ and $20-25 \mathrm{~cm})$ and two shallower layers $(2-5$ and $5-10 \mathrm{~cm})(p \leq 0.05)$. The maximum burrowing depth of both groups was correlated with their total density in the entire core (Fig. 3).

There was a positive correlation between densities of Tubificinae and C. balatonicus larvae (Fig. 4). Their cooccurrence was most often recorded up to a depth of $10 \mathrm{~cm}$ (Fig. 5) and proved to be significant in the $0-2 \mathrm{~cm}$ (Pearson's Chi-Square $(\mathrm{df}=1)=7 ; p \leq 0.008)$ and $2-5 \mathrm{~cm}$ layers (Pearson's Chi-Square $(\mathrm{df}=1)=50 ; p<0.001)$. In the two deepest layers $(15-20$ and $20-25 \mathrm{~cm})$, the frequency of both groups was much lower, and Tubificinae and $C$. balatonicus were never found together in the same sample.
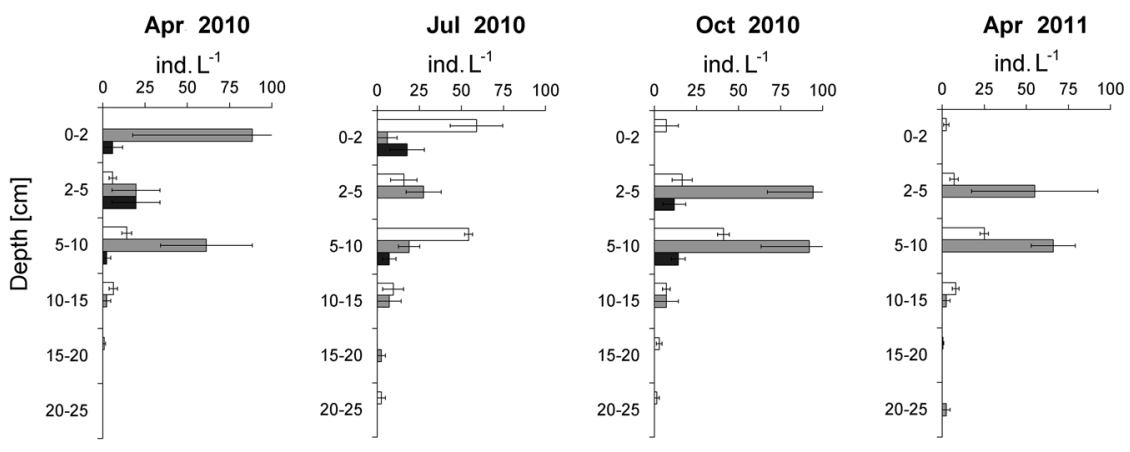

$\square$ Chironomus balatonicus

$\square$ Potamothrix hammoniensis

- Limnodrilus hoffmeisteri
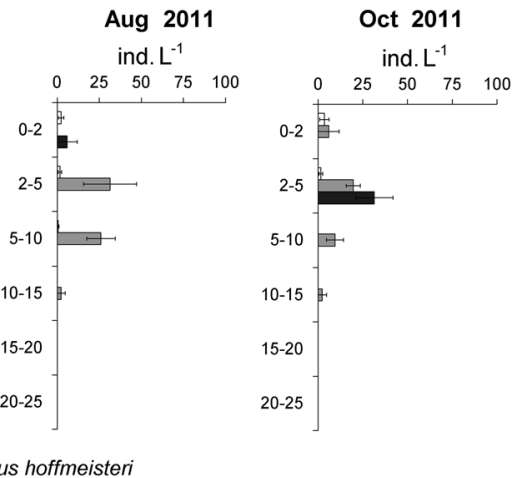

Fig. 2 Density of Tubificinae and Chironomus balatonicus larvae along the sediment profile in the Vistula Lagoon. Values are means \pm SEM (Standard Error of the Mean) for sampling occasions

Table 1 Friedman Chi-Square $\left(\chi^{2}\right)$ test for the effect of sediment depth on the density of Chironomus balatonicus and Tubificinae in the Vistula Lagoon

\begin{tabular}{lllllll}
\hline & Apr 2010 & Jul 2010 & Oct 2010 & Apr 2011 & Aug 2011 & Oct 2011 \\
\hline $\begin{array}{l}\text { Chironomus } \\
\text { balatoni- }\end{array}$ & $\begin{array}{c}\chi^{2}(n=9, \mathrm{df}=5)=24 ; \\
\mathrm{p}<0.01\end{array}$ & $\begin{array}{c}\chi^{2}(n=7, \mathrm{df}=5)=19 ; \\
\mathrm{p}<0.01\end{array}$ & $\begin{array}{c}\chi^{2}(n=10, \mathrm{df}=5)=32 ; \\
\mathrm{p}<0.01\end{array}$ & $\begin{array}{c}\chi^{2}(n=15, \\
\mathrm{df}=5)=46 ;\end{array}$ & $\begin{array}{c}\chi^{2}(n=15, \mathrm{df}=5)=6 ; \\
\mathrm{NS}\end{array}$ & $\begin{array}{c}\chi^{2}(n=15, \\
\mathrm{df}=5)=8 ;\end{array}$ \\
$\begin{array}{c}\text { cus } \\
\text { Tubificinae }\end{array}$ & $\begin{array}{c}\chi^{2}(n=9, \mathrm{df}=5)=29 ; \\
\mathrm{p}<0.0001\end{array}$ & $\begin{array}{c}\chi^{2}(n=3, \mathrm{df}=5)=9 ; \\
\mathrm{p}<0.1\end{array}$ & $\begin{array}{c}\chi^{2}(n=5, \mathrm{df}=5)=21 ; \\
\mathrm{p}<0.0007\end{array}$ & $\begin{array}{c}\chi^{2}(n=15, \\
\mathrm{df}=5)=52 ;\end{array}$ & $\begin{array}{c}\chi^{2}(n=15, \mathrm{df}=5)=50 ; \\
\mathrm{p}<0.0001\end{array}$ \\
& & & $\mathrm{p}<0.0001$ & $\begin{array}{c}\chi^{2}(n=15, \\
\mathrm{df}=5)=49 ; \\
\mathrm{p}<0.0001\end{array}$ \\
\hline
\end{tabular}

NS not significant 

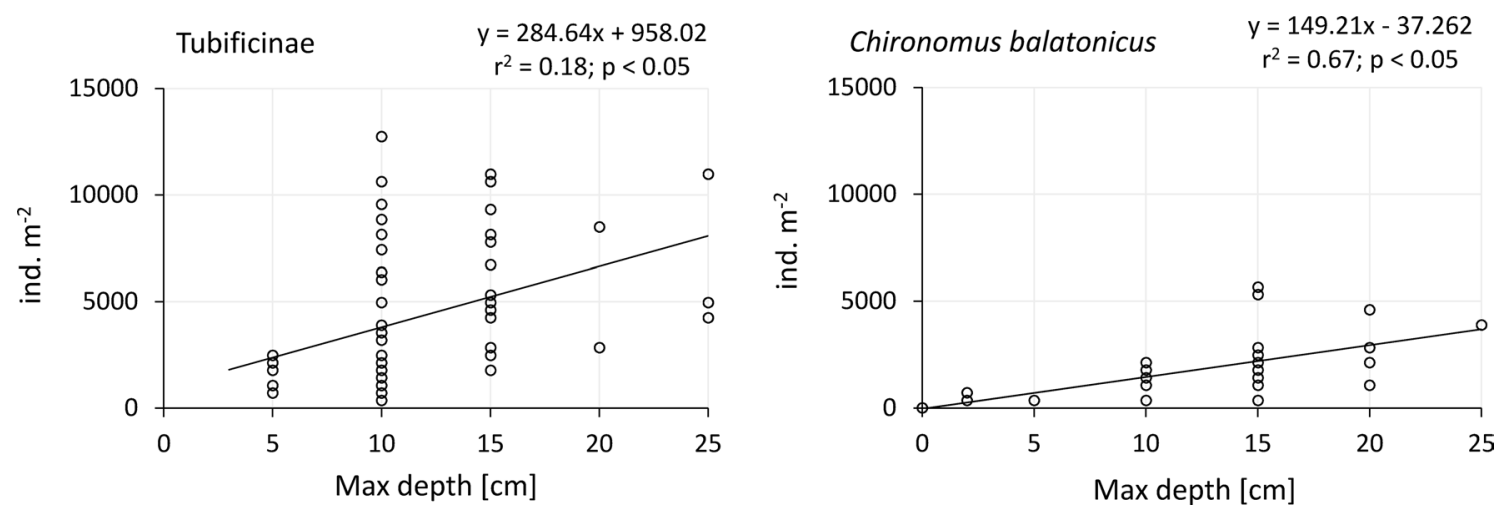

Fig. 3 Linear regression analysis of the relationship between invertebrate density in entire sediment core and maximum burrowing depth in the Vistula Lagoon

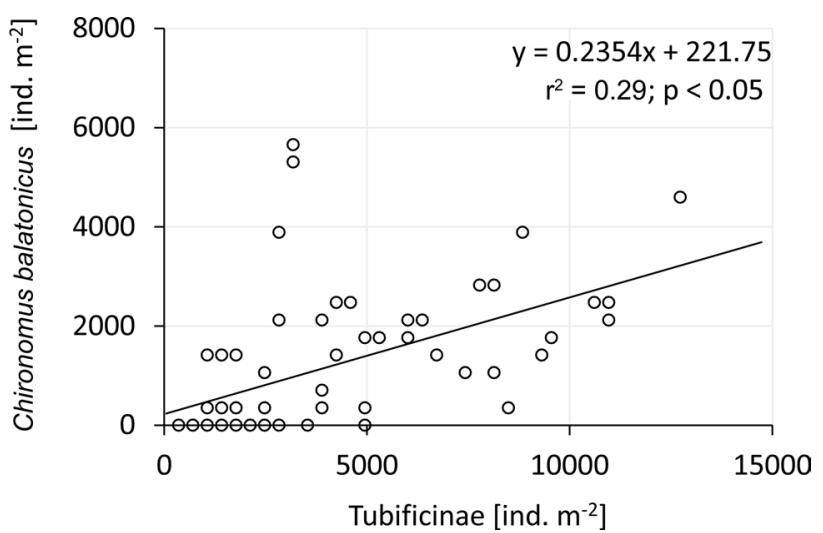

Fig. 4 Relationship between the densities of Tubificinae and Chironomus balatonicus larvae in sediment cores

\section{Proxies for nutritional conditions in the sediments}

Values of organic matter content in the sediment profile ranged from 8 to $11 \%$, and were aligned in the sediment profile [Kruskal-Wallis $\mathrm{H}(n=21)=6 ; p=0.39$ ]. The concentration of bacteria seemed to be the highest between 15 and $25 \mathrm{~cm}$, but differences between the layers were insignificant [Kruskal-Wallis H $(n=21)=6 ; p=0.42$ ].

\section{Discussion}

The habitat conditions in the Vistula Lagoon, including high concentrations of nutrients and low transparency due to resuspension and the development of phytoplankton corresponded to those in other Baltic costal shallow and highly eutrophic lagoons and estuaries. Their organic matter-rich silty sediments are beneficial particularly for non-selective detritivorous Oligochaeta and chironomid larvae, known to build high densities (Ezhova et al. 2005; Gasiunaite et al. 2008; Radziejewska and Schernewski 2008; Wolnomiejski and Witek 2013; Kornijów and Pawlikowski 2015; Golubkov et al. 2019). However, the mutual distribution of these invertebrates in the sediment is very little known.

In our study the maximum burrowing depth by Tubificinae and C. balatonicus larvae in the Vistula Lagoon positively correlated with their densities (Fig. 3). A similar relationship was found for Tubificinae living in rivers (Brinkhurst and Kennedy 1965) and lakes (McCall and
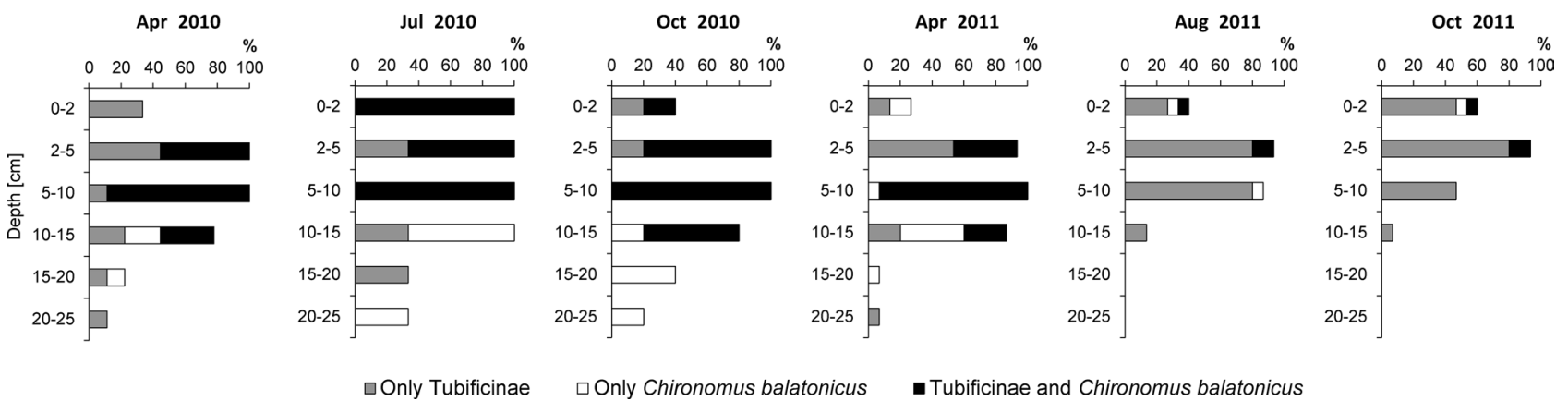

Fig. 5 Frequency (\%) of occurrence of Tubificinae alone, Chironomus balatonicus alone, or both groups together along the sediment profile in the Vistula Lagoon 
Fisher 1980), as well as in experimental conditions (Robbins et al. 1979). According to McCall and Tevesz (1982), deeper burrowing may be related to the rate of exploitation of food resources. At low densities, the rate is low and there is no need for burrowing deeper. The opposite situation might occur at high densities, when food shortage in superficial layers can sooner or later appear. Such situations could take place in the studied lagoon, where the highest density of bacteria was recorded deeper than that of the majority of invertebrates. This could force animals to exploit deeper sediment layers.

The relationship between density and burrowing depth by Chironomus larvae might be related to the larval size structure. Because larger individuals tend to burrow deeper (Kajak and Dusoge 1971; Kornijów and Pawlikowski 2015), in a larger population the probability of occurrence of big individuals can be assumed to be greater, and therefore deeper burrowing can be expected.

A general positive relationship was found between densities of Tubificinae and C. balatonicus (Fig. 4). The density and joint frequency of occurrence of both groups were highest in the upper $10 \mathrm{~cm}$ sediment (Figs. 5 and 6). In addition, only in this depth range co-occurrence proved to be significant. The results suggest lack of antagonistic interactions between Tubificinae and C. balatonicus, including lack of competition for space, which supports our hypothesis. A similar conclusion was drawn based on the established correlation between the density of Chironomus plumosus (L.) larvae and Tubificinae (mainly Potamothrix hammoniensis) in a long-term series of more than twenty years of research in other large and shallow water bodies, namely in the southern Baltic Szczecin Lagoon by Wolnomiejski (1994) and in Estonian Lake Võrtsjärv by Kangur et al. (1998).
The vertical distribution of $C$. balatonicus and Tubificinae in bottom sediments, their distinct diets and modes of physical disturbance suggests their complementary role in the processing of organic matter. A hypothetical model for such role, based on the data of the present study and literature review, is presented in Fig. 7. Tube-dwelling chironomid larvae live in self-ventilated U-shaped, J-shaped, or Y-shaped tubes, and feed on filtered suspension or particles collected from the sediment. A substantial fraction of the detrital material is not assimilated by the animals, and the undigested remains are excreted deeper in the sediment. This applies not only to detritus particles, but partly also to bacteria and certain groups of algae (Kajak and Warda 1968; Baker and Bradnam 1976; Hirabayashi and Wotton 1998). In this way, the larvae, acting as downward conveyors (Mermillod-Blondin 2011; Kristensen et al. 2012), contribute to the transport and decomposition of organic matter to deeper sediment layers.The subsurface sediment enriched by chironomid larvae is in turn a feeding place of Tubificinae. Worms are believed to feed in the upper $15 \mathrm{~cm}$ sediment layer (Davis 1974; McCall and Fisher 1980; Fukuhara 1987). They selectively digest some organic components, transport them vertically upward through their gut, and defecate at the sediment surface (biodeposition) (Davis 1974; Fukuhara 1987; Nogaro et al. 2007; Timm and Martin 2015). They are considered upward belt-conveyors enriching the surface sediment layer with fine organic matter (Andersson et al. 1988), which might be of potential importance for chironomid surface collectors. Therefore, Chironomus larvae and Tubificinae, representing basically the same trophic guild (detritivores), live in a shared habitat, but use space and food resources differently, and the consequences of their burrowing and feeding behaviour are opposing. As a result of the activity of tube-dwelling Chironomus larvae,
Fig. 6 Percentage of organic matter (LOI) and concentrations of bacteria along the sediment profile in the Vistula Lagoon Values are means \pm SEM for sampling occasions
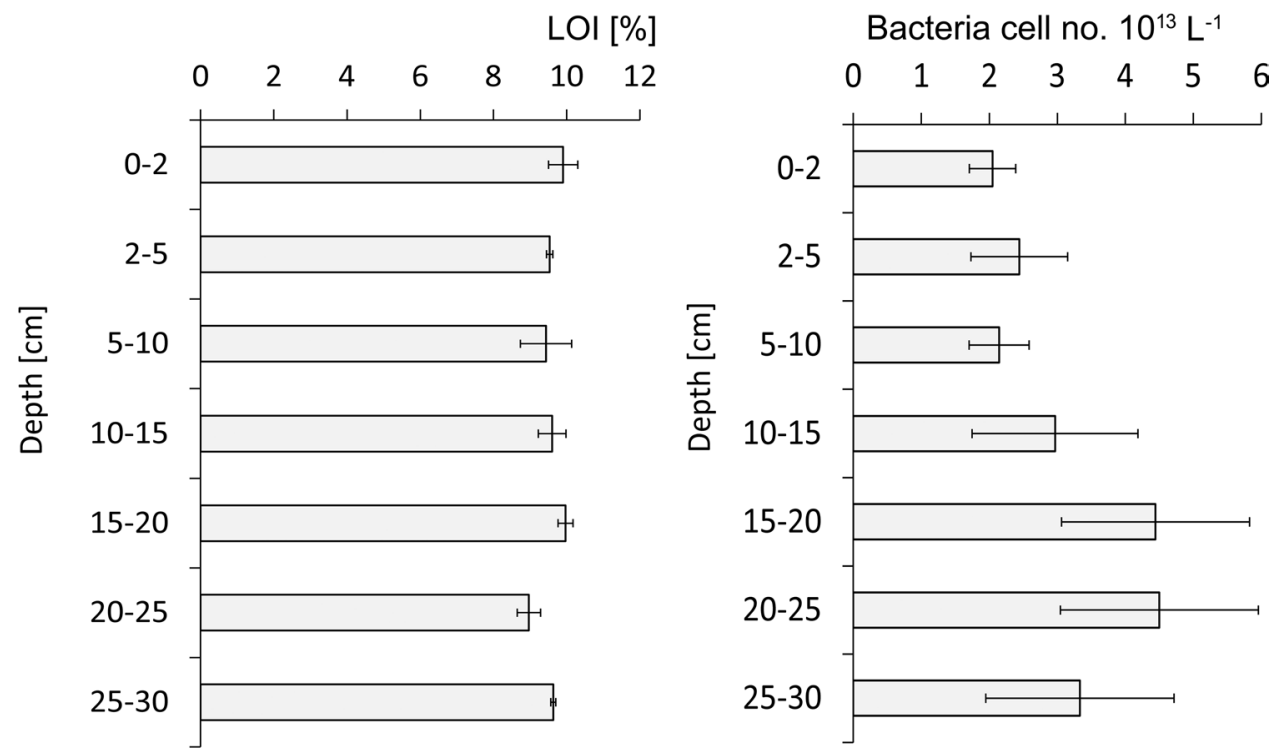
Fig. 7 Conceptual scheme of activity and relationships between Tubificinae and tubedwelling Chironomus larvae, and the resulting direction of matter circulation (arrows). Bioprocessing signifies activity of shredders, fungi and bacteria

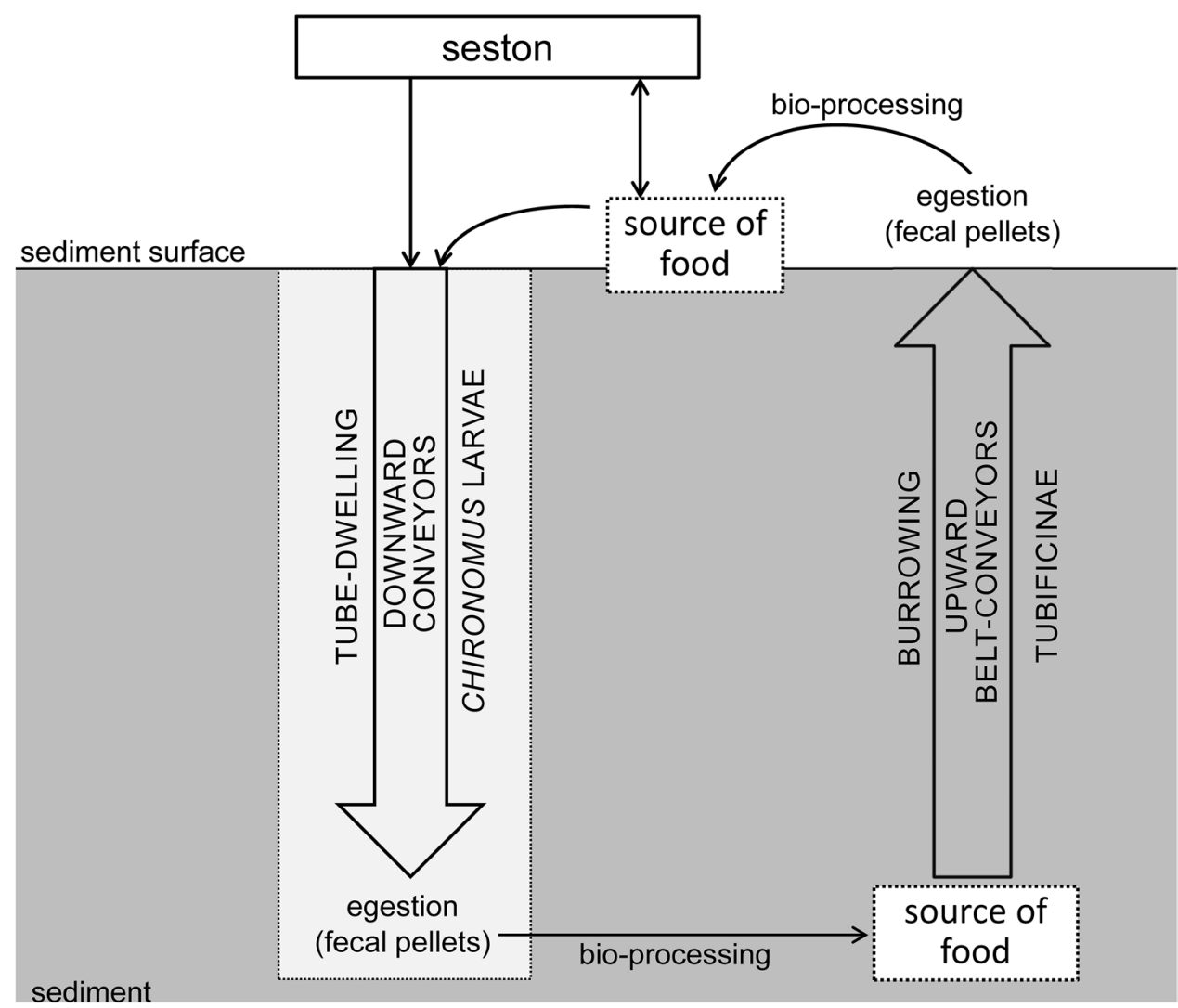

the nutritional value of surface sediment layers decreases while that of deeper located sediments increases (Lewandowski and Hupfer 2005; Hölker et al. 2015). The effect of worms' activity is the opposite; the top of the sediment becomes covered by fecal pellets, and the underlying layers become more silt-clayish (Timm and Martin 2015). Thus, their requirements and ecological roles (called niches) seem not to overlap, preventing competitive exclusion and allowing for co-occurrence.

It is uncertain to what extent the invertebrates' activity and their environmental structural effect are important for both groups. Chironomus larvae are probably less dependent on oligochaetes than vice versa, because they can take food not only from the sediments (enriched by the activity of worms), but also from the water column. Oligochaetes may in turn benefit from sediment enrichment only after the abandoned tubes decay and fecal pellets are processed by meiofauna and bacteria (McLachlan et al. 1979; Van de Bund et al. 1994). Therefore, this relationship can be extended in time. This may explain the fact that in the Vistula Lagoon a strong decrease of the density of $C$. balatonicus larvae in the second year of this study did not result in a simultaneous decrease of the Tubificinae population.

Frequently observed strong dominance, or even the exclusive occurrence of one of the groups, may not to be a result of biotic interactions such as opportunistic predation by Chironomus larvae, as suggested by Loden (1974) and Jónasson and Thorhauge (1976), or competition for food, claimed by other authors (Brinkhurst and Kennedy 1965; Jónasson 1972; Moss and Timms 1989). Assuming the constant pressure by fish and invertebrate predators, it may be determined by specific local habitat conditions (e.g. quantity and quality of food, inorganic pollution or organic matter loads and resulting water and sediment oxygenation), to which various invertebrates respond differently. This would be justified by the fact that the density ratio between chironomids and oligochaetes is used in predictive ecology to estimate pollution and/or eutrophication in estuaries (Como and Magni 2009; Silva et al. 2012), lakes (Wiederholm 1980; Lang 1999; Burlakova et al. 2018), and rivers (Goodnight 1973; Rosa et al. 2014; Gorzel et al. 2018). This suggests that research on different drivers of species co-occurrence might be not only of theoretical interest, but can also be a source of new information on the functioning of benthic communities and ecological status of an ecosystem (Cazelles et al. 2016).

Acknowledgements The paper is a result of the NMRFI statutory research project DOT 18/Lagoon (Trophic interactions and their consequences for water quality in the Vistula Lagoon under anticipated increase in human pressure), supported by the Polish Ministry of Science and Higher Education. We are grateful to Prof. Nick Gotelli, University of Vermont, for his advice in choosing proper co-occurrence 
test. We also thank the Editor and two anonymous reviewers who highly contributed to the final version of the article.

\section{Declarations}

Conflict of interest The authors declare that they have no conflicts of interest.

Open Access This article is licensed under a Creative Commons Attribution 4.0 International License, which permits use, sharing, adaptation, distribution and reproduction in any medium or format, as long as you give appropriate credit to the original author(s) and the source, provide a link to the Creative Commons licence, and indicate if changes were made. The images or other third party material in this article are included in the article's Creative Commons licence, unless indicated otherwise in a credit line to the material. If material is not included in the article's Creative Commons licence and your intended use is not permitted by statutory regulation or exceeds the permitted use, you will need to obtain permission directly from the copyright holder. To view a copy of this licence, visit http://creativecommons.org/licenses/by/4.0/.

\section{References}

Andersen T, Cranston PS, Epler JH (2013) The larvae of Chironomidae (Diptera) of the Holarctic region-keys and diagnoses. Insect Syst Evol 2013:189

Andersson G, Graneli W, Stenson J (1988) The influence of animals on phosphorus cycling in lake ecosystems. Hydrobiologia 170:267-284. https://doi.org/10.1007/Bf00024909

Armitage PD, Cranston PS, Pinder LCV (1995) The Chironomidae. Biology and ecology of non-biting midges. Chapman and Hall, Londyn-Madryt

Baker JH, Bradnam LA (1976) The role of bacteria in the nutrition of aquatic detritivores. Oecologia 24:95-104. https://doi.org/ $10.1007 / \mathrm{bf} 00572753$

Beghelli FGD, dos Santos ACA, Urso-Guimaraes MV, Calijuri MD (2012) Relationship between space distribution of the benthic macroinvertebrates community and trophic state in a Neotropical reservoir (Itupararanga, Brazil). Biota Neotrop 12:114-124. https://doi.org/10.1590/S1676-06032012000400012

Brinkhurst RO, Kennedy CR (1965) Studies on the biology of the Tubificidae (Annelida, Oligochaeta) in a polluted stream. J Anim Ecol 34:429-443. https://doi.org/10.2307/2659

Burlakova LE, Kovalenko KE, Schmude KL et al (2018) Development of new indices of Great Lakes water quality based on profundal benthic communities. J Great Lakes Res 44:618-628. https://doi.org/10.1016/j.jglr.2017.11.004

Cazelles K, Araújo MB, Mouquet N, Gravel D (2016) A theory for species co-occurrence in interaction networks. Theor Ecol 9:39-48. https://doi.org/10.1007/s12080-015-0281-9

Chubarenko BV (2008) The Vistula lagoon. In: Chubarenko BV (ed) Transboundary waters and basins in the south-east Baltic. Terra Baltica, Kaliningrad, pp 37-57

Chubarenko B, Margoński P (2008) The Vistula Lagoon. In: Schiewer U (ed) Ecology of Baltic coastal waters. Ecol St (Anal Synth), vol 197. Springer, Berlin, pp 167-195

Como S, Magni P (2009) Temporal changes of a macrobenthic assemblage in harsh lagoon sediments. Estuar Coast Shelf $S$ 83:638-646. https://doi.org/10.1016/j.ecss.2009.05.024

Covich AP, Palmer MA, Crowl TA (1999) The role of benthic invertebrate species in freshwater ecosystems: zoobenthic species influence energy flows and nutrient cycling. BioScience 49:119-127. https://doi.org/10.2307/1313537

Davis RB (1974) Stratigraphic effects of tubificids in profundal lake sediments. Limnol Oceanogr 19:466-488. https://doi.org/10. 4319/1o.1974.19.3.0466

Epstein SS, Rossel J (1995) Methodology of in situ grazing experiments: Evaluation of a new vital dye for preparation of fluorescently labeled bacteria. Mar Ecol Prog Ser 128:143-150. https:// doi.org/10.3354/meps 128143

Ezhova E, Żmudziński L, Maciejewska K (2005) Long-term trends in the macrozoobenthos of the Vistula Lagoon, southeastern Baltic Sea. Species composition and biomass distribution. Bull Sea Fish Inst 1:55-73

Fukuhara H (1987) The effect of tubificids and chironomids on particle redistribution of lake sediment. Ecol Res 2:255-264. https://doi. org/10.1007/bf02349778

Gasiunaite ZR, Daunys D, Olenin S, Razinkovas A (2008) The Curonian Lagoon. In: Schiewer U (ed) Ecology of Baltic coastal waters, Ecological Studies (Analysis and Synthesis), vol 197. Springer. Berlin, Heidelberg, pp 197-216. https://doi.org/10.1007/ 978-3-540-73524-3

Golubkov SM, Golubkov MS, Tiunov AV (2019) Anthropogenic carbon as a basal resource in the benthic food webs in the Neva Estuary (Baltic Sea). Mar Pollut Bull 146:190-200. https://doi. org/10.1016/j.marpolbul.2019.06.037

Goodnight C (1973) Use of aquatic macroinvertebrates as indicators of stream pollution. T Am Microsc Soc 92:1-13. https://doi.org/ $10.2307 / 3225166$

Gorzel M, Kornijów R, Buczyńska E (2018) Quality of rivers: comparison of hydro-morphological, physical-chemical and biological methods. Ecol Chem Eng S 25:101-122. https://doi.org/10.1515/ eces-2018-0007

Gotelli NJ, Ellison AM (2013) A primer of ecological statistics, 2nd edn. Sinauer Associates Inc, Sunderland Massachusetts USA

Hirabayashi K, Wotton RS (1998) Organic matter processing by chironomid larvae (Diptera: Chironomidae). Hydrobiologia 382:151159. https://doi.org/10.1023/a:1003472329603

Hölker F, Vanni MJ, Kuiper JJ et al (2015) Tube-dwelling invertebrates: tiny ecosystem engineers have large effects in lake ecosystems. Ecol Monogr 85:333-351. https://doi.org/10.1890/14-1160.1

Holland JN, DeAngelis DL (2009) Consumer-resource theory predicts dynamic transitions between outcomes of interspecific interactions. Ecol Lett 12:1357-1366. https://doi.org/10.1111/j.14610248.2009.01390.x

Jónasson PM (1972) Ecology and production of profundal benthos in relation to phytoplankton in Lake Esrom. Oikos, Suppl, p 14

Jónasson PM, Thorhauge F (1976) Population dynamics of Potamothrix hammoniensis in the profundal of Lake Esrom with special reference to environmental and competitive factors. Oikos 27:193-203. https://doi.org/10.2307/3543898

Juget J, Yi BJ, Roux C, Richoux P et al (1979) Structure and functioning manner of the ecosystems in the Upper French Rhone. VII. The hydrographic complex of the Lône des-Pêcheurs, a former bed of the Rhône. Schweiz Z Hydrol 41:395-417

Kajak Z, Dusoge K (1971) The regularities of vertical distribution of benthos in bottom sediments of three Masurian lakes. Ekol Pol 19:485-499

Kajak Z, Warda J (1968) Feeding of benthic non-predatory Chironomidae in lakes. Ann Zool Fenn 5:57-64

Kangur K, Timm H, Timm T, Timm V (1998) Long-term changes in the macrozoobenthos of Lake Võrtsjärv. Limnologica 28:75-83

Kornijów R (1997) The impact of predation by perch on the size-structure of Chironomus larvae-the role of vertical distribution of the prey in the bottom sediments, and habitat complexity. Hydrobiologia 342:207-213. https://doi.org/10.1023/A:1017067621668 
Kornijów R (2013) A new sediment slicer for rapid sectioning of the uppermost sediment cores from marine and freshwater habitats. J Paleolimnol 49:301-304. https://doi.org/10.1007/ s10933-012-9655-9

Kornijów R (2018) Ecosystem of the Polish part of the Vistula Lagoon from the perspective of alternative stable states concept, with implications for management issues. Oceanologia 60:390-404. https://doi.org/10.1016/j.oceano.2018.02.004

Kornijów R, Karpowicz M, Ejsmont-Karabin J et al (2020) Patchy distribution of phyto- and zooplankton in large and shallow lagoon under ice cover and resulting trophic interactions. Mar Freshw Res 71:1327-1341. https://doi.org/10.1071/MF19259

Kornijów R, Markiyanova M, Lange E (2019) Feeding by two closely related species of Chironomus (Diptera: Chironomidae) in south Baltic lagoons, with implications for competitive interactions and resource partitioning. Aquat Ecol 53:315-324. https://doi. org/10.1007/s10452-019-09691-7

Kornijów R, Moss B (1997) Vertical distribution of in-benthos in relation to fish and floating-leaved macrophyte populations. In: Jeppesen E, Søndergaard M, Søndergaard M, Christoffersen K (eds) Structuring Role of Subbmerged Macrophytes in Lakes. Ecol St (Anal Synth). Springer, New York, pp 227-232

Kornijów R, Pawlikowski K (2015) Three-dimensional microdistribution of Chironomus balatonicus larvae (Chironomidae, Diptera) in soft sediments from the Vistula Lagoon (South Baltic Sea). Ann Limnol-Int J Lim 51:343-349. https://doi.org/10. 1051/limn/2015034

Kornijów R, Pawlikowski K (2016) A common error in calculating the density of invertebrates in sediment core sections of unequal lengths. Ann Limnol Int J Lim 52:301-306. https://doi.org/10. 1051/limn/2016017

Kownacka J, Całkiewicz J, Kornijów R (2020) A turning point in the development of phytoplankton in the Vistula Lagoon (southern Baltic Sea) at the beginning of the 21 st century. Oceanologia 62:538-555. https://doi.org/10.1016/j.oceano.2020.08.004

Kristensen E, Penha-Lopes G, Delefosse M et al (2012) What is bioturbation? The need for a precise definition for fauna in aquatic sciences. Mar Ecol Prog Ser 446:285-302. https://doi.org/10. 3354/meps09506

Lang C (1999) Contrasting responses of oligochaetes (Annelida) and chironomids (Diptera) to the abatement of eutrophication in Lake Neuchatel. Aquat Sci 61:206-214. https://doi.org/10. 1007/PL00001324

Lewandowski J, Hupfer M (2005) Effect of macrozoobenthos on two-dimensional small-scale heterogeneity of pore water phosphorus concentrations in lake sediments: a laboratory study. Limnol Oceanogr 50:1106-1118. https://doi.org/10.4319/lo. 2005.50.4.1106

Loden MS (1974) Predation by chironomid (Diptera) larvae on oligochaetes. Limnol Oceanogr 19:156-159. https://doi.org/10. 4319/1o.1974.19.1.0156

Magni P, De Falco G, Como S, Casu D, Floris A, Petrov AN, Castelli A, Perilli A (2008) Distribution and ecological relevance of fine sediments in organic-enriched lagoons: the case study of the Cabras lagoon (Sardinia, Italy). Mar Pollut Bull 56:549-564. https://doi.org/10.1016/j.marpolbul.2007.12.004

Maritime Office in Gdynia (2015) Urząd Morski w Gdyni-MapyDane GIS/CAD. http://www.umgdy.gov.pl. Accessed 17 August, 2015

Markiyanova MF (2018) Species composition and distribution of sibling species Chironomus Meigen (Diptera: Chironomidae) in the Curonian and Vistula lagoons. Oceanology 58:710-716. https://doi.org/10.1134/S0001437018050065

Mathooko JM (1995) Vertical distribution of macrozoobenthos and coarse particulate organic matter in the sediment surface of a pool biotope in the Njoro River Kenya. Arch Hydrobiol 133:95-106

Matisoff G, Wang XS, McCall PL (1999) Biological redistribution of lake sediments by tubificid oligochaetes: Branchiura sowerbyi and Limnodrilus hoffmeisteri/Tubifex tubifex. J Great Lakes Res 25:205-219. https://doi.org/10.1016/S0380-1330(99)70729-X

McCall PL, Fisher JB (1980) Effects of tubificid oligochaetes on physical and chemical properties of Lake Erie sediments. In: Brinkhurst RO, Cook DG (eds) Aquatic oligochaete biology. Springer, Boston, pp 253-317. https://doi.org/10.1007/978-1-4613-3048-6_16

McCall PL, Tevesz MJS (1982) Chapter 3. The effects of benthos on physical properties of freshwater sediments. In: McCall PL, Tevesz MJS (eds) Animal-sediment relations. Topics in geobiology. Springer, Boston, pp 105-176. https://doi.org/10.1007/ 978-1-4757-1317-6_3

McLachlan AJ, Cantrell MA (1976) Sediment development and its influence on distribution and tube structure of Chironomus plumosus L (Chironomidae, Diptera) in a New Impoundment. Freshwater Biol 6:437-443. https://doi.org/10.1111/j.1365-2427.1976. tb01632.x

McLachlan AJ, Pearce LJ, Smith JA (1979) Feeding interactions and cycling of peat in a bog lake. J Anim Ecol 48:851-861. https:// doi.org/10.2307/4198

Mermillod-Blondin F (2011) The functional significance of bioturbation and biodeposition on biogeochemical processes at the watersediment interface in freshwater and marine ecosystems. J N Am Benthol Soc 30:770-778. https://doi.org/10.1899/10-121.1

Milbrink G (1973) On the vertical distribution of oligochaetes in lake sediments. Institute for Freshwater Research Rep., Drottningholm

Moss B, Timms M (1989) Predation, sediment stability and food availability as determinants of the benthic invertebrate fauna in two shallow lakes. Hydrobiologia 185:249-257. https://doi.org/10. 1007/Bf00036613

Mucha AP, Vasconcelos MTSD, Bordalo AA (2004) Vertical distribution of the macrobenthic community and its relationships to trace metals and natural sediment characteristics in the lower Douro estuary, Portugal. Estuar Coast Shelf S 59:663-673. https://doi. org/10.1016/j.ecss.2003.11.010

Nawrocka L, Kobos J (2011) The trophic state of the Vistula Lagoon: an assessment based on selected biotic and abiotic parameters according to the Water Framework Directive. Oceanologia 53:881-894. https://doi.org/10.5697/oc.53-3.881

Newrkla P, Wijegoonawardana N (1987) Vertica distribution and abundance of benthic invertebrates in profundal sediments of Mondsee, with special reference to oligochaetes. Hydrobiologia 155:227234. https://doi.org/10.1007/Bf00025655

Nogaro G, Mermillod-Blondin F, Montuelle B, Boisson JC, Lafont M, Volat B, Gibert J (2007) Do tubificid worms influence organic matter processing and fate of pollutants in stormwater sediments deposited at the surface of infiltration systems? Chemosphere 70:315-328. https://doi.org/10.1016/j.chemosphere.2007.06.002

Odum EP (1971) Fundamentals of ecology. Toronto, W.B Saunders Company, Philadelphia

Ojaveer E (2017) Life in the Baltic Sea. In: Ojaveer E (ed) Ecosystems and Living Resources of the Baltic Sea. Their assessment and management. Springer, New York, pp 49-208

OpenStreetMap (2020) OpenTopoMap. https://a.tile.opentopomap.org. Accessed via QGIS OSM plugin 18 November 2020

Persson A, Svensson JM (2006) Vertical distribution of benthic community responses to fish predators, and effects on algae and suspended material. Aquat Ecol 40:85-95. https://doi.org/10.1007/ s10452-005-9014-2

Pinder LCV (1995) The habitats of chironomid larvae. In: Armitage PD, Cranston PS, Pinder LCV (eds) Chironomidae. Springer, Dordrecht, pp 107-135. https://doi.org/10.1007/ 978-94-011-0715-0_6 
Piwosz K, Kownacka J, Ameryk A, Zalewski M, Pernthaler J (2016) Phenology of cryptomonads and the CRY1 lineage in a coastal brackish lagoon (Vistula Lagoon, Baltic Sea). J Phycol 52:626637. https://doi.org/10.1111/jpy. 12424

Proulx I, Hare L (2014) Differences in feeding behaviour among Chironomus species revealed by measurements of sulphur stable isotopes and cadmium in larvae. Freshw Biol 59:73-86. https://doi. org/10.1111/fwb.12247

Radziejewska T, Schernewski G (2008) The Szczecin (Oder-) Lagoon. In: Schiewer U (ed) Ecology of Baltic Coastal Waters. Ecol St (Anal Synth), vol 197. Springer, Berlin, pp 121-129

Rosa BJFV, Rodrigues LFT, de Oliveira GS, Alves RG (2014) Chironomidae and Oligochaeta for water quality evaluation in an urban river in southeastern Brazil. Environ Monit Assess 186:77717779. https://doi.org/10.1007/s10661-014-3965-5

Robbins JA, McCall PL, Fisher JB, Krezoski JR (1979) Effect of deposit feeders on migration of 137Cs in lake sediments. Earth Planet Sci Lett 42:277-287. https://doi.org/10.1016/0012821X(79)90035-9

Silva ACF, Tavares P, Shapouri M et al (2012) Estuarine biodiversity as an indicator of groundwater discharge. Estuar Coast Shelf $S$ 97:38-43. https://doi.org/10.1016/j.ecss.2011.11.006

StatSoft (2011) Statistica software version 10. StatSoft Inc. http://www. statsoft.com. Accessed 26 May, 2020

Timm T (1999) A guide to the Estonian Annelida. Estonian Academy Publishers, Tallinn

Timm T, Martin PJ (2015) Chapter 21. Clitellata: Oligochaeta. In: Thorp J, Rogers DC (eds) Ecology and general biology, 4th edn. Academic Press, Amsterdam, pp 529-549. https://doi.org/10. 1016/B978-0-12-385026-3.00021-8
Van de Bund WJ, Groenendijk D (1994) Seasonal dynamics and burrowing of littoral chironomid larvae in relation to competition and predation. Arch Hydrobiol 132:213-225

Van de Bund WJ, Goedkoop W, Johnson RK (1994) Effects of depositfeeder activity on bacterial production and abundance in profundal lake sediment. J N Am Benthol Soc 13:532-539. https:// doi:https://doi.org/10.2307/1467849

Vos JH (2001) Feeding of detritivores in freshwater sediments. PhD thesis. University of Amsterdam, Amsterdam

Walshe BM (1947) Feeding mechanisms of Chironomus larvae. Nature 160:474-474. https://doi.org/10.1038/160474a0

Whitlach RB (1980) Patterns of resource utilization and coexistance in marine intertidal deposit-feeding communities. J Mar Res 38:743-765

Wiederholm T (1980) Use of benthos in lake monitoring. J Water Pollut Control Fed 52:537-547

Wolnomiejski N (1994) Ecological study on muddy bottom macrofauna of the Szczecin Lagoon (1982-1992). Mor Inst Ryb Gdynia, ser. A, Stud Mat, p 31

Wolnomiejski N, Witek Z (2013) Szczecin Lagoon ecosystem: the biotic community of the Great Lagoon and its food web model. De Gruyter. https://doi.org/10.2478/9788376560502

Publisher's Note Springer Nature remains neutral with regard to jurisdictional claims in published maps and institutional affiliations. 